らう。俳し非分泌性中耳「カタール」の症例をも輕

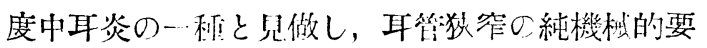

約に冈る非炎症性中耳カタールの仿在苍全面的に 否是できるか否かは今後の破究に俟つの他ない。

\title{
「ベッオルド」氏流注膿場を思はしめた 後顽骨急性感染性骨櫄炎症例
}

川口醫學專問學校耳鼻咽顺科教室

教授 本庶 正一

小倉記念病院耳鼻咽㮢科

野崎薩夫 • 吉田俊明

\section{緒言}

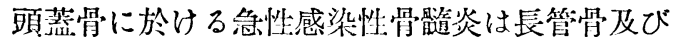
他の扇平骨，短骨の場命に比し極严て稀であり， Soheiznissによれば酳魚骨に於けるものは總ての 急性感染性:骨髓炎1782例中僅かに9 例である。又

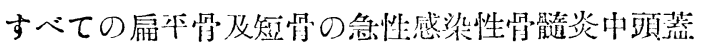
骨に於けるものは，Soheiznissによれば 3.03\%， A.V. Bergmann に上れば27例中 3 例, Fiöhner によれば 10 例中 9 例走活めてるる。

吾々は最近後頭骨に於ける急性感染性骨慥炎の 1 例支經驗したので茲に報告する。敢へて此の 1 例起城告する理小は二つある。郎ち，第１は本例 が局所所見として右側頸部及右乳柡哭起尖端下お

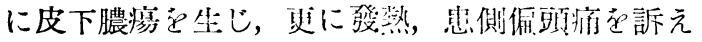
加えるに右慢性中耳化膿症があり，而も存唄嘼骨 の「レ線像に於いて一部䗋漅の骨融解芫認めたの で，本例の右側頸部及右;乳㥞突起尖端下方にある

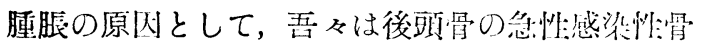

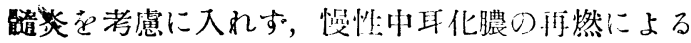

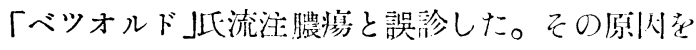

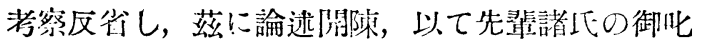
評を仰ざ度いためである。第 2 は，本例に於ける

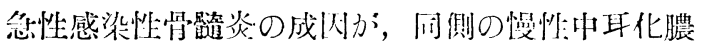

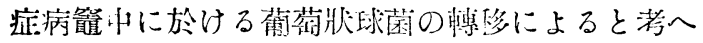

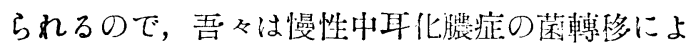
る合作症として本例の急性感染性滑䯕炎走取上け たいからである。

\section{症例}

\author{
患者 7 于男子, 初診, 昭和23年 5 月 28 日。

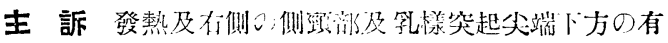
痛性腄脤。

家族鋫 特訅す心゙き项なし。

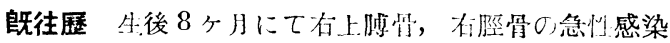

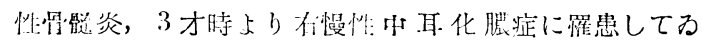
る。

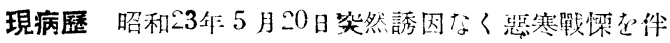
ひ發熱(40度)し，同月22日より次第に有僛顽部及右乳㧼

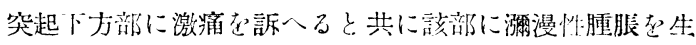

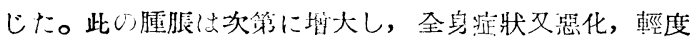

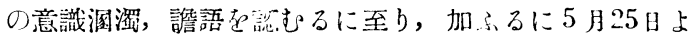
๖一日に 3 乃至 4 回嘔叶が市り，5月28日に至るも39

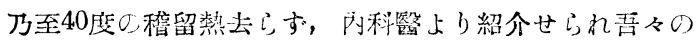

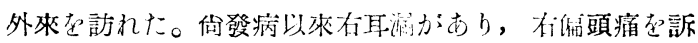
へてるる。

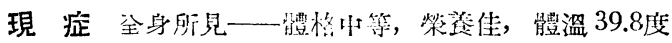

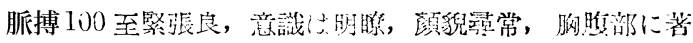

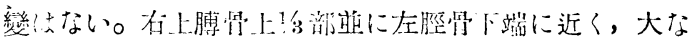
る手術創般痕がある。四肢の腱父射何何孔正常。

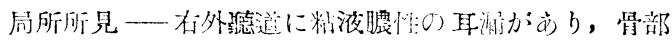

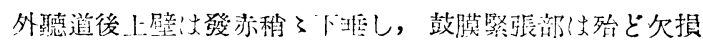

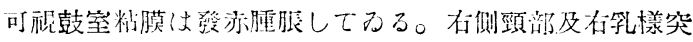

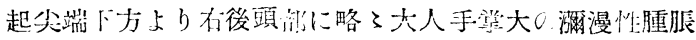

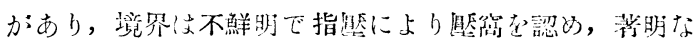

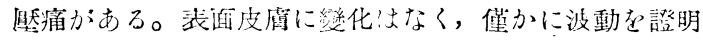
する。左正及上氣道に著戀はない。项部强㨁, 外旋神經

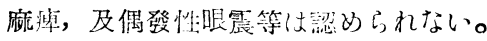

血液所兄 $(5$ 月 58 日 ) 一一赤血球数 $350 \mathrm{Jj}$, 白血球數 
15000, 白血球百分比, 監基好性:白血球 $0 \%$ $\%$ 「デン」

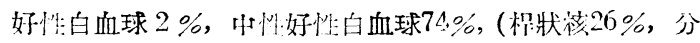
烡狀核 $48 \%$ ，淋巴球 $16 \%$, 大單核縕胞 $8 \%$ 。

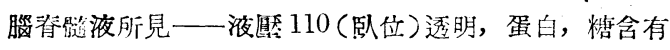

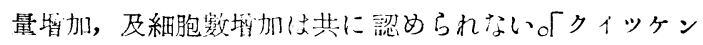
ステット氏」現象陰恻:。

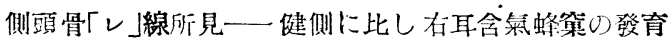

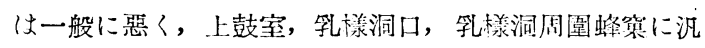

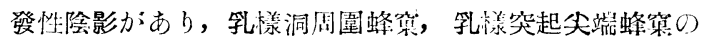
一部に胃融解か認められる。

經過及處置 以上の所見及热檢查成績上り吾了は本例

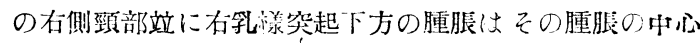
が稍了後方に位し，ためにその位管的條件より些か定形 的ではないか，全身症狀及耳所見老考愿し，本例在右幔 性山耳化膿症の再然による「ベッォルド」氏流注眼演と考 へろのか最も妥當と思し， 5 月28日右耳後部に皮切老加

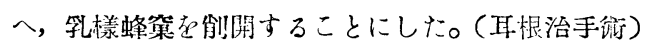

右耳後部の皮下には膿济なく，乳樣笑起外面特に尖端

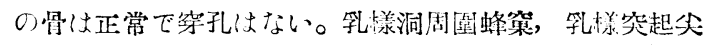

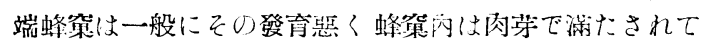

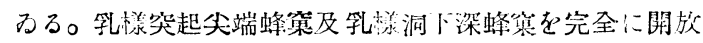

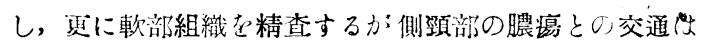
全く見出されない。そこで新たに腫脤の中心に於て切開 を加へると黄白色濃厚な大量の膘汁老排出し, 切開創內

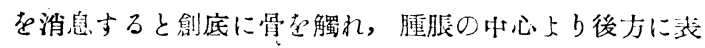
面粗造な後頭骨定触知した。消息子に上万探索及滞韵い

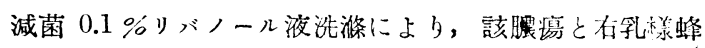

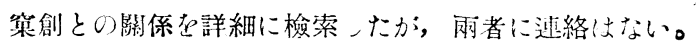

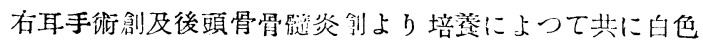
葡蒛狀球菌虎檢出し得た。術後「ペニシリン」「サルジー ル」の筋注射, 內胑等を坆行しだ。術後第四日目から解

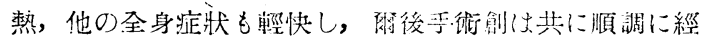

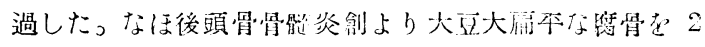
個排州した。

\section{考按}

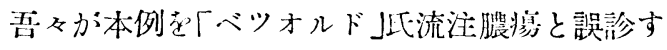
るに至つた原因茲に教然して見たい。

第1）本例に於て最も䓡落な局所所見としては 右側頸部及右乳橙突起尖端下方に大人手掌大の沉

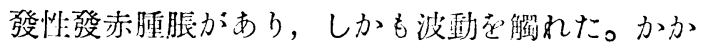

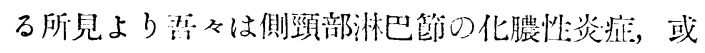
は「ベツオルド」氏流注膿瘍を考へた。

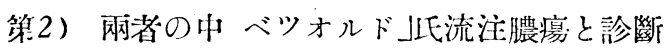
した理的は，1）全身症候が㷙者にしては餘りに
激しいこと。之のために吾々は一應は「チフス性

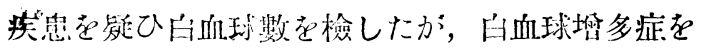
示した。2）侧项部の發赤腫脤と间側の耳に慢性 中耳化膿症があり，しかも同症再然の徴候が認め られる。3）同側の唄副骨の「レ，線像に一部蜂巢 の骨融解を認める。以上の諸點から吾々は「ベツ オルド」氏流注膿惶と䛦断した。

第3）しかし，その發赤腫脤の位置が秒了後方 に偏してるたために一挍の疑念をいけが゙るを得 なかつたか，前記第202），3）は之党打消すに充 分の力を吾々に添へた。而して望々は该頭骨の急 恻感染临骨髅炎は少しも考虑に入れなかつた。

第け）然し，橎つて考入て見ると，後頭骨の骨 䯕炎を考へさせるに充分な事實がないわけではな い。即ち，1）既往症として生後 8 ケ月で急性骨 䯣炎に矔腎してるる。2）全身症狀が激烈である 等は本例急性:骨䯣炎と考入るに无分な资料吾 そに舆へてるる。萬一本例に於て同側の慢性中耳 化膿症の闻然の徵候が焎かつたなら, 吾々も值ち に「ヘッオルド㧧注膿瘍とは診斷を下さなかつ たであらう。

第5）茲に吾々の誤沴の原们がある樣に思はれ る。之は淺學菲才な吾从のみがおかす過であるか

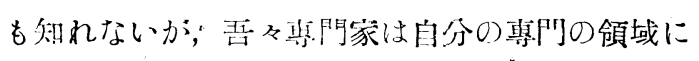

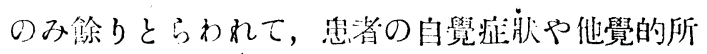

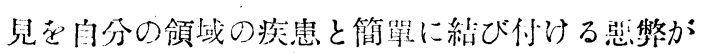
ある。本例がての一つの㳖はれである。

なほ吾々は本例より得た經驗からでッ゙ルド」

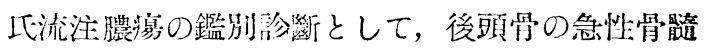
炎も考へる必要のあること芷捉示したい。

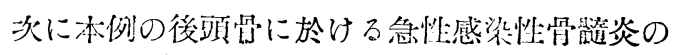
成生機轉に就て考察して兄たい。一般に頭蓝骨の 急性滑檤炎の發生機轉に關しては，1）頭莣骨損

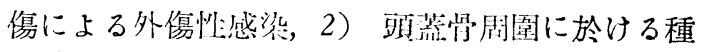

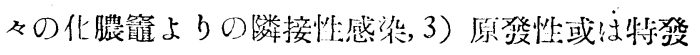
恻感染，4）他の化膿筐上り血行を介する轉移性 感染の匹つの場们があり，㠺に幼年期に於ては轉 移性感染が比較的多いと云はれてるる。さて本例

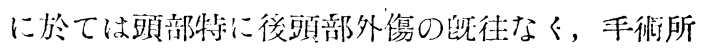

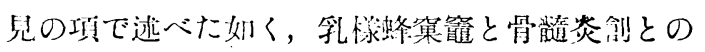
洴には肉腿的迅絡は淧められない。文後頭部の皮 膚表面には原發箒と思はれるものもない。故に本 


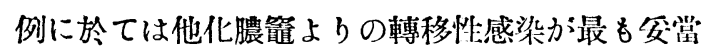
と思将せられる。而して本例に䣄ける中耳化膿病: の起炎菌は培養の絬果葡菊狀球菌であり，後部留 の骨䯣炎創の起炎菌も同柡の蒇蕧狀球菌である。 したがつて後頭部の急性感染性骨䯕炎は，茂萄狀

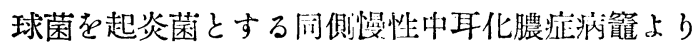
の轉移性感染に因つて發生したものと䓅へるのか： 最も適當であると思考せられる。

\section{結 論}

稀有な疾患である後歌骨急性感染性骨骨檤炎の 1

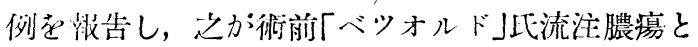
誤まられた原因尼考察し，沜せて本例に於ける後

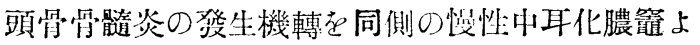
つの轉移州感染によるものと維明した。

（文献略）

\section{「ムコーズス」性耳炎の臨床細菌學的診糹に就て}

\section{富 樫 準 一}

Schottmüller 及び Wittmaack 以來 ム性耳 炎に關しては，廣く矅告されているか，今日尚，

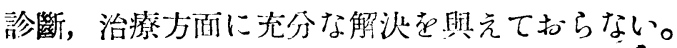

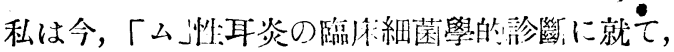
統計的に觀察した絬果尼䋐告する。

「ム性耳炎の取扱いに就て，Urk:nt chitsch，

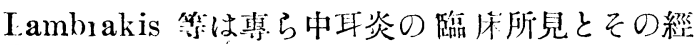
過から荆斷さるべきもので，平漏或は乳㥞蜂窠內 の膿汁中に「ム」菌が證明されす，他の菌が證明さ

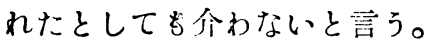

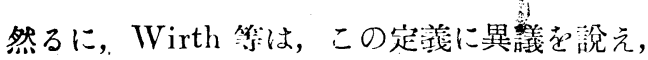
「么惺耳炎と山病巢加ら「公菌在證朋するもの に限局すべきであつて，栾称的所見从び縃過から

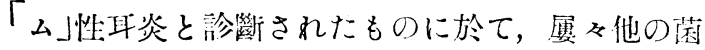
が證明されることを指摘し，このようにくム性耳 炎の症彇，經過走示すか，何等一定の病原闻を見 出しえないものは，Mucosusotitis ohne Mucosus と言わす, Protrahierte Otitis, Otitis lenta 花し くは Mastoiditis lenta と言うべきであると言う。

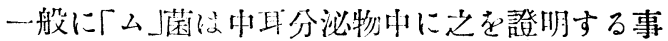
は相篦困難であるばかりでなく，双球菌を認めて もその刵走が容易でない事もあり，特に二次感浲

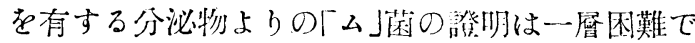
ある。これに反して，乳㥞䗋淉より得られた膿汁

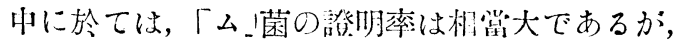
それでも润容易に詠明し得ない場今もある。

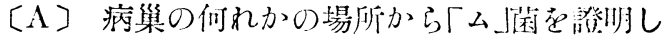

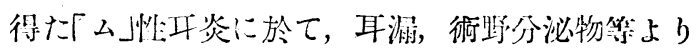
「ム」菌かどの位に檢等されるかに就ては，從來し つかりした統計的赧告か見窝らない。

私が，昭和10年 1 月より昭利21年12月までの間

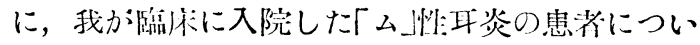
て檢心た絬果は表1の如くで，卯ち，耳潮よりは

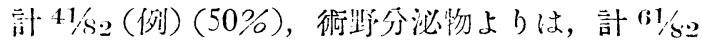

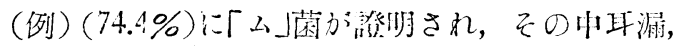

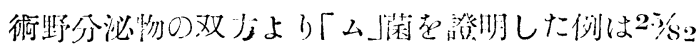

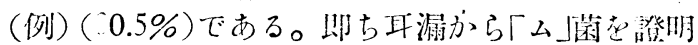

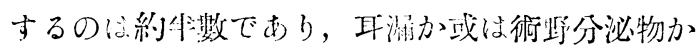
站 1 「ム」菌證明薪

\begin{tabular}{|c|c|c|c|c|c|c|c|c|c|}
\hline 材 & 耳 & 術 & 耳料 & 臘 & 腦 & 畺 & 耳 & 耳創 & 備 、 \\
\hline 菌 & 漏 & $\begin{array}{l}\text { 旺 } \\
\text { 分 } \\
\text { 泌 } \\
\text { 物 }\end{array}$ & 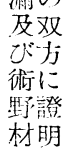 & 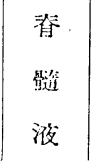 & 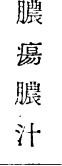 & $\begin{array}{l}\text { 分 } \\
\text { 泌 } \\
\text { 物 }\end{array}$ & $\begin{array}{l}\text { 跟 } \\
\text { 腸 } \\
\text { 膿 } \\
\text { 汁 }\end{array}$ & $\begin{array}{l}\text { 後 } \\
\text { 部分 } \\
\text { 切泌 } \\
\text { 開物 }\end{array}$ & 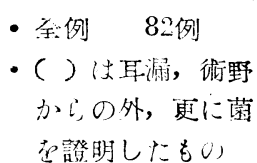 \\
\hline $\begin{array}{c}\text { 肺炎双球菌 } \\
\text { 第 III 型 }\end{array}$ & 16 & 36 & 25 & $5+(1)$ & (1) & (2) & (1) & (1) & \\
\hline
\end{tabular}

